\title{
Contemporary Gujarati Poetry: For Whom Are They Writing?
}

\author{
Mukesh Modi, \\ D. M. Patel Arts and S. S. Patel Commerce College
}

\begin{abstract}
:
The writer here describes the various ages and traditions of Gujarati Poetry, looks into the present condition and questions the practice of writing poetry for the pundits'sake.
\end{abstract}

\section{Middle Age Gujarati Poetry}

Gujarati poetry has basically evolved from Bhakti Literature of the $15^{\text {th }}$ and $16^{\text {th }}$ centuries. Oral tradition of Gujarati folklore dates back to the $12^{\text {th }}$ century. So many seekers/devotees contributed immensely to the development of Gujarati poetry. Gujarati literature is divided broadly into two periods. The period from $12^{\text {th }}$ century to the early $19^{\text {th }}$ century is known as Middle Age, and the second period from $19^{\text {th }}$ century to the beginning of the $20^{\text {th }}$ century is known as Modern age. Looking at the Middle Age Gujarati literature, we find that the period was, as is the case with other Indian literature, dominated by poetry. In Gujarati, we have Narsinh Mehta Mirabai, Akho, Premanand, Shamal, Dayaram, Bhalan, Nakar, Bhim, Raje, Pritam, Dhiro, Bhojo and many others. With few exceptions, most of these poets liked to be known as devotees more and poets less. As Dr. Ramesh Trivedi mentions: "There was neither a consciousness of being poets nor attachment to being poets." The central theme of Middle Age Gujarati Literature

Rupkatha Journal on Interdisciplinary Studies in Humanities

Summer Issue, Volume I, Number 1, 2009

URL of the journal: www.rupkatha.com/issue0109.php

URL of the article: www.rupkatha.com/0109contemporarygujaratipoetry.pdf

(C) www.rupkatha.com 
was religion. Since the society of the time was dependent heavily on religion, the hymns to devotions, wisdom and detachments were the major themes of the poetry of the age.

\section{Modern Gujarati Poetry}

As a cultural renaissance passed over India in the $19^{\text {th }}$ and $20^{\text {th }}$ centuries all over India, Gujarat was not in isolation and exception in the process. The social consciousness and the revolutionary mood against the Britishers as well as against the prevailing evils in the social structure were gaining momentum in the period. A person in social life was supposed to be carrying out the multiple tasks of being a leader in society, freedom fighter, spiritual seeker and many more. In short, that was a time of general practice (GP), if to use a medical term and not of specialization and super specialization. People of class were wearing many hats.

Modern Gujarati literature can be divided in to three periods, but with a caution as given by a linguist and a poet Narsinhrao Divetia: "...these lines are not rigidly marked ones...the flow of language cannot be compartmentalized...the transformation from one into other takes place unknowingly." So the three periods are:

1. 1850 to 1885: Reformation Age or Narmad Age.

2. 1885 to 1915: Pundit Age or Govardhan Age

3. 1915 to 1950 : Gandhi Age

The major poets of the Reformation Age were Narmad and Dalpatram. Again as they were specifically motivated towards social reformation, their poetry was more of a tool to that end. But under the influence of the Western literature, many genres like lyric, narrative poetry and elegy were imported in poetry. With the Pundit Age, there came the dominance of the graduates of the upcoming universities. As Dr. Ramesh Trivedi suggests: "Through study and contemplation, the scholar in these poets bloomed, so it is known as Pundit Age." And since Govardhan Tripathi (the creator of Saraswatichandra) was a major influence, this Age is also known as the Govardhan Age. The important poets were Manilal Dwivedi, Balashankar Kantharia, Narsinhrao Divetia, Kant, Kalapi, Nahnalal, 
Balwantrai Thakore and many more. The forms of lyric, elegy, epic, sonnet and ghazal were gaining prominence and shape.

The third phase of modern age is rightly known as Gandhi Age since the influence of Gandhi over life and literature was evident. The important poets of the Age are: Sundaram, Umashankar Joshi, Zaverchand Meghani, Snehrashmireflected the vision and mission of Gandhi in their poetry. Search for reality, love for dalits, village transformation, world peace and world brotherhood were some of the thematic concerns of the Gandhi Age poets. The life as well as literature of Gandhi Age was returning to the simplicity of thought and expression. The Pundit Age was under a tremendous pressure and the Gandhi Age poetry moved away from decorative style to the simplicity. Instead of idealism, reality was thought and expressed in literature. In this Age literature we find the naturality and freshness of ideas. The mass was also finding place in the literature of the time.

Perhaps this is the bouncing point of this article. Post 1950, Gujarati poetry can be divided, for our purpose, of course, into two groups:

(A) Poets who practice metrical poetry with traditional themes of love, parting, devotion, crisis, brotherhood, admiration etc.

(B) Poets who practice non-metric style and involve in the themes under the Western influence of absurdity and existentialism.

The poets who practice metrical poetry can be divided, again, in two groups:

(A) The poets who use simple language and simple expressions to appeal to non-poets also. They are lucid, fresh, full of innovation in thoughts and yet simple, approachable, enjoyable without the so called pre-requisite of scholarliness of the educated people.

(B) There are others who appeal to the so called scholarly people only. They experiment with form and substance only in order to be innovative for the sake of innovations. They assume that the more they are difficult to comprehend, the more they are great as poets. They feel proud if people feel bewildered at their poetry. Such are the poets who keep the profession of the critics alive (or dead!). Without the super knowledge of the critics, one dare not touch the poetry of such great poets. 
Again in the non-metrical poetry category, there are two sub-divisions, as with the metrical poetry group, one who are simple in style and substance and easily approachable, and the other beyond the means of common people.

I do believe that reading and enjoying poetry requires special skill rather an emotion of sympathy and a bit of sensitivity. Anything that requires mastery to understand and enjoy poetry cannot be poetry but something else. Poetry is the easiest tool God has given mankind to reach the heart of people of all class and category.

So the poets who attempt non-metric poetry and use simple words and expressions are the poets who can be easily read and understood. Eliot was a great poet, but the question is was he that great as Walt Whitman who was not only great but also belonged to the contemporary American society? To be a great is easy, since you can be made great as well, but to be greatly admired in the heart of people is difficult task. Gandhi, as a socio-political man was a great and superb but his greatness becomes altogether greater when we see him to be in oneness with the people of society. People never thought Gandhi as an alien factor. People always thought that there is a bit of Gandhi in them, they can also be great.

So here we are posing some questions/observations with reference to modern day Gujarati poetry:

- Who are the people reading Gujarati poetry?

- Do the people of Gujarat buy the books of poetry?

- Why does Gujarati poetry look foreign even to a person who is Gujarati by birth? Is it simply due to not having literary culture in Gujarat? Even if it is due to so, who are responsible for that?

- Why don't we find poetry regularly published in Gujarati newspapers and magazines?

- If a great Gujarati poet walks on the road of any city/village of Gujarat-how many people would recognize him?

- Is a poet born when he writes poetry or when he 'becomes' (or made) great as a poet? 
- Why do Gujarati poets still use language/words that are two hundred year old metaphors and rhyme having smell of past?

- How many Gujarati poets are from the professions other than the academic or education?

- Only a graduate or post-graduate in Gujarati or any other literature can be a poet in Gujarati? Is it a law?

- One recent example: A poet when he translated his poetry in to English became recognized easily. Why?

- Except Kavita, a bi-monthly Gujarati magazine of poetry edited by Suresh Dalal, which are other magazines ready to listen to the new voices of simplicity in the field of poetry?

There can be many more charges against the contemporary Gujarati poetry and poets. In Gandhi Age the simplicity of language and thought prevailed over the scholarly tone of the Pundit Age. Only in Gandhi Age, the poetry was the poetry of public. So do we not have the issues for poetry now? Surely we do have plenty. In this $21^{\text {st }}$ century, in the age of technology and 'visual', how can one attempt poetry as only a step of pedagogy only?

It is a responsibility of poets to be reachable to the people in whose language they are writing. If any speaker of your language, by chance, happen to come across a poem by a poet and even after an attempt he does not understand it, let it be clear that the fault lies not with the reader but the writer.

\section{References}

(All the reference books used/read for this article are written in Gujarati; hence the titles are given in working translation in English in brackets for the purpose of possible understanding as to the nature of the book)

- Brahmbhatt, Prasad. (2003) Kavyasarita. (Literary Criticism of the evolution of Poetry). Ahmedabad: Parshwa Publication.

- Trivedi, Ramesh. M. (1994) Arvachin Gujarati Sahityano Itihaas. (History of Modern Gujarati Literature). Ahmedabad: Adarsh Prakashan.

- Trivedi, Ramesh. M. (2005) Gujarati Sahityano Itihaas. (History of Gujarati Literature). Ahmedabad: Adarsh Prakashan. 
- Jani, Nutan. (2005) Vishvakavita: Kavita-Tulana (World poetry: Comparison of Poetry). Mumbai.

- Joshi, Vidyut. (2004) Sahitya ane Samaj (Literature and Society) Ahmedabad: Parshwa Publication.

Writer: Mukesh Modi, Head, Dept. of English, D. M. Patel Arts and S. S. Patel Commerce College, Ode. (Anand) Gujarat. E-mail: mukeshmodiin@yahoo.co.in 